\title{
MEMBANGUN ETOS KERJA GURU
}

\section{Syarifuddin}

STIT Al-Amin Kreo Tangerang

fawwazi45@yahoo.com

\begin{abstract}
:
In trying to develop teacher work ethos is feeling getting fair treatment: honest, healthy, just and etc. Teachers have to be aware that they are competent people. It means that they have to give big contribution for certain activity till the progress in teaching happens.
\end{abstract}

Keywords: Work Ethos, Competence, Progress. 


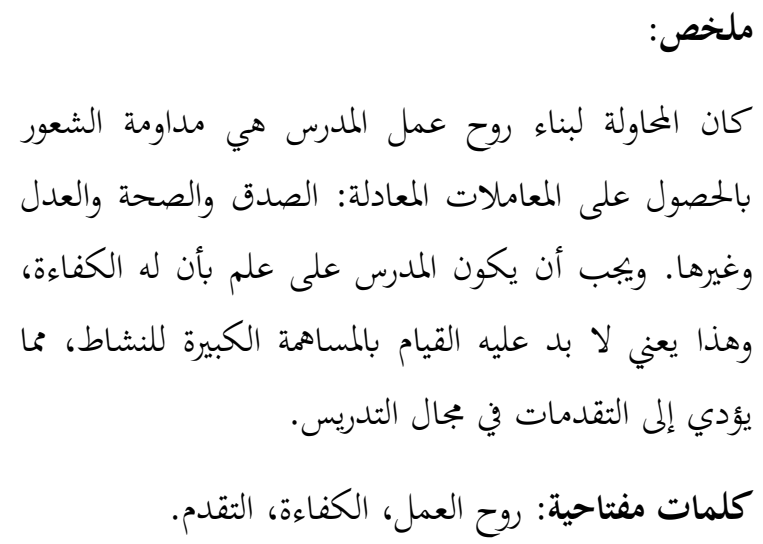

E

tos kerja merupakan ruh bagi terlaksananya

sebuah pekerjaan, dalam sebuah lembaga pendidikan formal, adanya etos kerja yang baik, penuh tanggung jawab, dan memiliki kualifikasi keahlian yang memadai adalah langkah strategis dalam menyukseskan seluruh program yang dimiliki oleh lembaga pendidikan formal tersebut.

Adalah sebuah refleksi yang penulis coba ungkapkan dalam sebuah coretan kecil ini terkait dengan bagaimana seorang guru dapat memulai kariernya, membangun persepsinya tentang dunia kerja yang akan dilakoninya, dan pada akhirnya dapat membangun etos kerjanya sebagai seorang tenaga profesional dalam menyikapi kesiapan dan kesadarannya dalam melaksanakan amanat suci sebagai tenaga pendidikan. Mengingat di samping tugasnya sebagai ujung tombak dalam menata dan mendesain anak didiknya agar mencapai keberhasilan dalam belajar, proses pendewasaan, dan peraihan prestasi akademik dengan tetap mengedepankan nilai, moral, dan etika sebagai jargon keberhasilan dalam pendidikan.

Guru dalam konteks ke-Indonesiaan mengacu pada empat dasar kompetensi, yakni kompetensi akademik, kompetensi personal, kompetensi profesional, dan kompetensi sosial. Keempat pilar kompetensi diatas merupakan standar bagi tenaga profesi guru. Sehingga untuk membangun etos kerja yang diinginkan, lembaga harus mengokohkan keempat pilar diatas sebagai standar bagi seluruh tenaga pendidikan yang direkrutnya. 


\section{Syarifuddin}

\section{A. Pengertian Etos Kerja Guru}

Kata 'etos' berasal dari Yunani, ethos yang berarti 'ciri sifat' atau 'kebiasaan, adat istiadat' atau juga 'kecenderungan moral, pandangan hidup' yang dimiliki oleh seseorang, suatu golongan atau suatu bangsa. ${ }^{1}$

Dari kata etos ini dikenal pula kata etika, etiket yang hampir mendekati pada pengertian akhlak atau nilai-nilai yang berkaitan dengan baik buruk (moral), sehingga dalam etos tersebut terkandung gairah atau semangat yang amat kuat untuk mengerjakan sesuatu secara optimal, lebih baik dan bahkan berupaya untuk mencapai kualitas kerja yang sesempurna mungkin. ${ }^{2}$

Karena etika berkaitan dengan nilai kejiwaan seseorang, maka hendaknya setiap pribadi harus mengisinya dengan kebiasaan-kebiasaan yang positif dan ada semacam kerinduan untuk menunjukkan kepribadiannya dalam bentuk hasil kerja serta sikap dan perilaku yang menuju atau mengarah kepada hasil yang lebih sempurna. Dengan demikian etos adalah ciri atau sifat; sikap, kebiasaan, atau adat-istiadat; kecenderungan moral (norma) serta cara seseorang, suatu golongan atau suatu bangsa dalam memandang, menghayati, meyakini dan melaksanakan sesuatu.

Kerja menurut beberapa intelektual didefinisikan dengan definisi yang berbeda-beda menurut sudut pandang masing-masing. Adapun mengenai definisi kerja tersebut dapat kita perhatikan sebagai berikut:

Beberapa intelektual mendefinisikan kerja sebagai berikut:

\section{Abdul Aziz al-Khayyat}

Kerja dalam pengertian luas adalah semua bentuk usaha yang dilakukan manusia, baik dalam hal materi atau nonmateri, intelektual atau fisik, maupun hal-hal yang berkaitan dengan masalah keduniaan atau keakhiratan. ${ }^{3}$

1 Mochtar Bukhori, Pendidikan Dalam Pembangunan, (Yogyakarta: Tiara Wacana, 1994), h. 40.

2 Toto Tasmara, Membudayakan Etos Kerja Islami, (Jakarta: Gema Insani Pers, 2002), h. 15.

3 Abdul Aziz al-Khayyat, Nazrah al-Islām Li al-'Āmah Wa Aśaruhu Fī al-Tanmiyah, atau Etika Bekerja dalam Islam, terj. Moh. Nurhakim, (Jakarta: Gema Insani Press, 1994), h. 13. 
Adapun pengertian kerja secara khusus adalah setiap potensi yang dikeluarkan manusia untuk memenuhi tuntutan hidupnya berupa makanan, pakaian, tempat tinggal, dan peningkatan taraf hidupnya. ${ }^{4}$

2. The Liang Gie

Yang dimaksud dengan 'kerja' adalah keseluruhan pelaksanaan aktivitas jasmaniah dan rohaniah yang dilakukan oleh manusia untuk mencapai tujuan tertentu atau mengandung suatu maksud tertentu. ${ }^{5}$

3. Ali Sumanto al-Khindi

Kerja adalah suatu cara untuk memenuhi kebutuhan manusia baik kebutuhan fisik, psikologis, maupun sosial. ${ }^{6}$

Jadi bisa penulis simpulkan bahwa kerja merupakan keseluruhan bentuk usaha manusia yang meliputi pelaksanaan aktivitas jasmaniah dan rohaniah untuk memenuhi kebutuhannya, baik kebutuhan fisik yang meliputi makanan, pakaian, dan tempat tinggal, maupun kebutuhan psikologis yang mengarah kepada kepuasan diri, serta kebutuhan sosial yang berbentuk penghargaan masyarakat pada dirinya atas pekerjaan yang telah dilakukannya.

Setelah memperhatikan definisi etos dan beberapa definisi tentang kerja yang dikemukakan oleh beberapa intelektual, juga akan dikemukakan beberapa definisi tentang etos kerja sebagai suatu kesatuan makna yang dikemukakan oleh beberapa ahli, diantaranya yaitu:

a. Menurut Mochtar Bukhori

Etos kerja artinya ialah sikap terhadap kerja, pandangan terhadap kerja, ciri-ciri atau sifat mengenai cara bekerja, yang dimiliki seseorang, suatu golongan atau suatu bangsa. ${ }^{7}$

b. Menurut Abdul Razak

4 Abdul Aziz al-Khayyat, Nazrah al-Islām Li al-'Āmah Wa Aśaruhu Fī al-Tanmiyah, atau Etika Bekerja dalam Islam, h. 22.

5 The Liang Gie, Cara Bekerja Efisien, (Yogyakarta: Karya Kencana, 1978), h. 11.

6 Ali Sumanto al-Khindhi, Bekerja sebagai Ibadah: Konsep Memberantas Kemiskinan, Kebodohan, dan Keterbelakangan Umat, (Solo: CV. Aneka, 1997), h. 41.

7 Mochtar Bukhori, Pendidikan Dalam Pembangunan, h. 40.

214| Al Amin: Jurnal Kajian Ilmu dan Budaya Islam, Volume 1, No 2, 2018 


\section{Syarifuddin}

Etos kerja dalam Islam merupakan manifestasi kepercayaan seorang muslim bahwa kerja memiliki kaitan dengan tujuan hidupnya, yaitu memperoleh perkenan Allah. ${ }^{8}$

c. Menurut Toto Tasmara

Etos kerja muslim itu dapat didefinisikan sebagai cara pandang yang diyakini seorang muslim bahwa bekerja itu bukan saja untuk memuliakan dirinya, menampakkan kemanusiannya, tetapi juga sebagai suatu manifestasi dari amal shaleh dan oleh karenanya, mempunyai nilai ibadah yang sangat luhur. ${ }^{9}$

d. Menurut Pandji Anoraga

Etos kerja adalah suatu pandangan dan sikap bangsa atau satu umat terhadap kerja. ${ }^{10}$

Dari beberapa definisi tentang etos kerja yang telah dikemukakan oleh para intelektual di atas, penulis mengambil suatu kesimpulan bahwa etos kerja merupakan pandangan terhadap kerja, yaitu pandangan bahwa bekerja tidak hanya untuk memuliakan diri atau untuk menampakkan kemanusiaannya tetapi juga sebagai manifestasi amal saleh (karya produktif), yang karenanya memiliki nilai ibadah yang sangat luhur yaitu untuk memperoleh perkenan Allah. Dari pandangan inilah kemudian muncul sikap terhadap kerja.

Etos kerja juga dapat dilihat sebagai ciri-ciri mengenai cara bekerja yang dimiliki oleh seseorang, suatu golongan atau suatu bangsa.

Jika dikaitkan dengan guru maka etos kerja guru dapat diartikan sebagai sikap terhadap kerja, pandangan terhadap kerja, dan ciri-ciri mengenai cara bekerja yang dimiliki oleh seorang guru.

\section{B. Dasar-dasar Etos Kerja dalam Islam}

Pembahasan mengenai pandangan Islam tentang etos kerja ini barangkali dapat dimulai dengan usaha menangkap makna sedalam-dalamnya sabda Nabi saw yang amat

8 Abdul Rozak, dkk, Etos Kerja Mendorong Produktivitas Umat Beragama di Abad Dua Satu, (Jakarta: Zikrul Hakim, 1997), h. 208.

9 Toto Tasmara, Etos Kerja Pribadi Muslim, (Jakarta: PT. Dana Bhakti Wakaf, 1995), h. 28.

10 Panji Anoraga, Psikologi Kerja, (Jakarta: Rineka Cipta, 1992), h. 29. 
terkenal bahwa nilai setiap bentuk kerja itu bergantung pada niat-niat yang dipunyai pelakunya: jika tujuannya tinggi (seperti tujuan mencapai ridha Allah) maka ia pun akan mendapatkan nilai kerja yang tinggi, dan jika tujuannya rendah (seperti hanya bertujuan memperoleh simpati sesama manusia belaka), maka setingkat itu pulalah nilai kerjanya tersebut. Sabda Nabi saw yang mencerminkan penjelasan di atas adalah sebagai berikut:

"Sesungguhnya (nilai) segala pekerjaan itu adalah (sesuai) dengan niat-niat yang ada, dan setiap orang akan memperoleh apa yang ia niatkan...," (HR. Bukhari dan Muslim). ${ }^{11}$

Sabda Nabi tersebut menegaskan bahwa nilai kerja manusia tergantung pada komitmen yang mendasari kerja itu. Tinggi-rendah nilai kerja itu diperoleh seseorang sesuai dengan tinggi-rendah nilai komitmen yang dimiliki. Adapun komitmen atau niat adalah suatu bentuk pilihan dan keputusan pribadi yang dikaitkan dengan sistem nilai yang dianut oleh seseorang. Karena itu komitmen atau niat juga berfungsi sebagai sumber dorongan batin untuk mengerjakan atau tidak mengerjakan sesuatu, atau jika ia mengerjakannya, maka ia mengerjakannya dengan tingkat kesungguhan yang tertentu.

Selain sabda Nabi di atas yang lebih menyoroti pada niat untuk melakukan suatu pekerjaan ada juga firman Allah yang berpesan untuk bekerja, yaitu dalam surat al-Jumu'ah ayat 10 sebagai berikut:

"Apabila telah ditunaikan sembahyang, maka bertebaranlah kamu di muka bumi; dan carilah karunia Allah dan ingatlah Allah banyak-banyak supaya kamu beruntung," (QS. al-Jumu'ah [62]: 10). ${ }^{12}$

Jadi, maksud dari pesan itu ialah bahwa hendaknya kita beribadah sebagaimana yang diwajibkan, namun di sisi lain juga harus mencari rezeki (bekerja). Bersamaan dengan itu, seseorang harus senantiasa ingat kepada-Nya, yakni memenuhi semua ketentuan etis dan akhlak dalam bekerja

11 Yusuf bin Ismail al-Nabhani, Mukhtaṣar Riyād al-Sālihīn, (Beirut-Lebanon: Dar Ibnu Hazm, 1996), h. 10-11.

12 Yayasan Penyelenggara Penerjemah al-Qur`an, Al-Qur`an dan Terjemahnya, (Surabaya: Mahkota, 1971), h. 933.

216| Al Amin: Jurnal Kajian Ilmu dan Budaya Islam, Volume 1, No 2, 2018 


\section{Syarifuddin}

itu, dengan menginsafi pengawasan dan perhitungan Allah terhadap setiap bentuk kerja.

\section{Komponen Etos Kerja}

Lebih jelasnya mengenai pandangan terhadap kerja, sikap terhadap kerja, dan ciri-ciri mengenai cara bekerja akan penulis uraikan satu persatu sebagai berikut:

\section{Pandangan Terhadap Kerja}

Islam memiliki pandangan sangat positif terhadap kerja. Pandangan yang sangat positif tersebut dapat kita lihat bahwa kerja dalam Islam bukan semata-mata untuk bekerja. Kerja juga tidak murni perkara biasa, tidak hanya perilaku duniawi, bukan sekadar mengejar gaji, juga bukan semata untuk menepis gengsi, misalnya tudingan sebagai penganggur, tetapi kesadaran kerja dalam Islam, berlandaskan semangat tauhid dan tanggung jawab ketuhanan. Semua aktivitas keseharian seorang mukmin, termasuk kerja, diniatkan dan diorientasikan sebagai ibadah untuk mencapai ridha Allah. Hal ini dikarenakan masing-masing dari mereka mengetahui maksud hadits berikut:

"Sesungguhnya (nilai) segala pekerjaan itu adalah (sesuai) dengan niat-niat yang ada, dan setiap orang akan memperoleh apa yang ia niatkan," (HR. Bukhari dan Muslim). ${ }^{13}$

Mengenai pandangan terhadap kerja yang dimiliki oleh seorang guru, WS. Winkel mengatakan bahwa apakah seorang guru itu bekerja terutama untuk mendapatkan penghasilan semaksimal mungkin ataukah untuk menyumbangkan tenaga dan pikiran bagi perkembangan generasi muda, pasti akan mewarnai tingkah laku guru itu, entah itu disadari atau tidak. ${ }^{14}$

Lebih lanjut ia juga mengatakan bahwa: "Guru yang pertama-tama memikirkan masalah pendapatan, memandang pekerjaannya sebagai sarana melulu untuk mendapatkan uang, bahkan sekolah dipandang sebagai

13 Yusuf bin Ismail al-Nabhani, Mukhtașar Riyāḍ al-Șālihīn, h. $10-11$.

14 WS. Winkel, Psikologi Pengajaran, (Jakarta: Grasindo, 1996), cet. ke-4, h. 196. 
organisasi penjamin kesejahteraan guru. Guru itu akan cenderung supaya penerimaan siswa baru ditentukan berdasarkan kemampuan ekonomi, cenderung memberikan pelajaran tambahan sebanyak mungkin yang dihonorkan tersendiri, dan mengajar di sekolah lain sebagai tenaga tidak tetap. Akibat lebih jauh adalah bahwa guru tidak sempat mempersiapkan pelajaran dengan baik. Sedangkan guru yang pertama-tama berniat menyumbangkan keahliannya demi perkembangan siswa akan memandang pekerjaannya sebagai sumber kepuasan pribadi, biarpun tidak lepas dari tantangan. Dia akan rela mengorbankan waktu dan tenaga lebih banyak daripada yang dituntut secara formal, sikap ini akan diketahui dan dihargai oleh siswa. Dia pun akan berusaha meningkatkan profesionalitasnya tanpa disuruh mengikuti penataran, karena tidak ingin bersikap minimalis dalam menghayati tugas pendidikan yang diserahkan kepada guru. Masalah pendapatan tentu dipikirkan juga, akan tetapi hal ini tidak mewarnai pikiran dan tindakan secara dominan. ${ }^{15}$

Dari pendapat yang telah dikemukakan oleh Winkel tersebut dapat diketahui bahwa ada dua jenis guru bila ditinjau dari cara guru tersebut memandang pekerjaannya. Jenis yang pertama yaitu, guru yang memandang pekerjaannya (mengajar) sebagai sarana mendapatkan penghasilan, dan jenis yang kedua yaitu guru yang memandang pekerjaannya sebagai sarana untuk menyumbangkan tenaga dan pikiran bagi generasi muda. Tampak dalam pendapat Winkel bahwa salah satu dari kedua jenis guru di atas lebih buruk dari yang lainnya. Hal ini bisa dilihat pada akibat yang ditimbulkan oleh pandangan masing-masing guru yang berbeda antara jenis yang pertama dengan jenis yang kedua. Jenis guru yang pertama yaitu guru yang memandang pekerjaannya sebagai sarana melulu untuk mendapatkan penghasilan membawa dampak pada beberapa tingkah laku yang kurang terpuji, seperti: sekolah dipandang sebagai organisasi penjamin kesejahteraan guru, pemikirannya yang lebih cenderung bahwa penerimaan siswa baru lebih didasarkan pada kemampuan ekonomi, mengajar di beberapa (banyak) sekolah lain sebagai tenaga tidak tetap

15 WS. Winkel, Psikologi Pengajaran. 


\section{Syarifuddin}

agar memperoleh honor yang lebih tinggi, dan sebagainya. Adapun jenis guru yang kedua yaitu guru yang memandang pekerjaannya sebagai sarana untuk menyumbangkan tenaga dan pikirannya demi perkembangan generasi muda yang akhirnya membawa dampak yang baik pada perilaku guru tersebut.

Dari sini dapat disimpulkan bahwa etos kerja guru yang memandang pekerjaannya sebagai sarana untuk menyumbangkan tenaga dan pikirannya bagi generasi muda lebih baik/lebih tinggi daripada guru yang memandang pekerjaannya sebagai sarana melulu untuk mendapatkan penghasilan. Akan tetapi, realitas yang ada sekarang ini menunjukkan bahwa tidak selamanya pendapat Winkel itu benar. Bagaimanapun juga guru itu manusia biasa yang juga membutuhkan materi untuk membiayai kehidupannya. Karenanya, boleh-boleh saja jika ia berpandangan bahwa mengajar itu untuk mendapatkan penghasilan selama itu tidak membawa akibat yang merugikan bagi pihak-pihak yang berkepentingan.

\section{Sikap atau Kebiasaan terhadap Kerja}

Kembali lagi pada pembahasan etos kerja. Etos kerja dalam arti sempit, merupakan sikap yang positif terhadap suatu pekerjaan. Atau adanya orientasi nilai yang memberikan semangat pada diri seseorang untuk melaksanakan suatu pekerjaan dengan baik. Menurut Carrington DJ sebagaimana dikutip oleh Nursyamsiyah Yusuf, etos kerja mengandung beberapa makna, antara lain sebagai berikut.

a. Memandang 'kerja keras' sebagai suatu nilai kebaikan.

b. Penggunaan waktu secara mangkus (efektif), dalam arti tidak membuang buang waktu dengan percuma.

c. Memandang disiplin sebagai nilai yang baik.

d. Sangat bersifat produktif.

e. Memiliki rasa bangga terhadap pekerjaannya.

f. Memiliki komitmen dan kesetiaan pada profesinya dan tempat mereka bekerja.

g. Berorientasi pada prestasi dan secara ajek berusaha mencapai karier yang tinggi dan untuk kemajuan. 
h. Adanya nilai positif terhadap sikap hidup hemat (ekonomis), jujur, dan investasi yang benar dalam memperoleh pendapatan/kekayaan. ${ }^{16}$

Kerja keras yang dimaksud di sini, menurut penulis adalah bekerja dengan sungguh-sungguh dan penuh ketekunan, bekerja tanpa kenal lelah, penuh semangat, seakan hidup tak akan pernah berakhir. Efektif berarti penggunaan waktu secara tepat sehingga tercapai perbandingan yang terbaik antara usaha yang dilakukan dengan hasil yang diperoleh.

Ali Imron mendefinisikan bahwa disiplin adalah suatu keadaan di mana sesuatu itu berada dalam keadaan tertib, teratur dan semestinya, serta tiada suatu pelanggaran-pelanggaran baik secara langsung maupun tidak langsung. ${ }^{17}$

Dari pengertian ini dapat diuraikan bahwa guru yang mempunyai etos kerja yang tinggi akan memandang disiplin sebagai nilai yang baik, yang karenanya, ia akan selalu berusaha menerapkan kedisiplinan itu dalam kehidupan sehari-hari, terutama di lingkungan sekolah demi kelancaran proses pembelajaran yang ia lakukan, sehingga segala sesuatunya berjalan dengan tertib, teratur, dan semestinya. Arti sebenarnya dari produktif adalah menghasilkan lebih banyak, dan berkualitas lebih baik, dengan usaha yang sama. ${ }^{18}$

Dengan demikian, diharapkan guru yang mempunyai etos kerja yang tinggi akan selalu berusaha ke arah yang lebih baik dan lebih baik lagi, dengan usaha yang relatif sama. Jika seseorang merasa bangga dengan pekerjaan yang dimilikinya, maka ia akan mempunyai rasa kesetiaan (loyalitas) pada profesi dan tempat mereka bekerja.

Demikian ini berarti jika seseorang merasa bangga terhadap profesinya sebagai guru, maka ia akan enggan

16 Nursyamsiyah Yusuf, "Motivasi Menjadi Guru dalam Kaitannya dengan Profil Kinerjanya", Jurnal Ilmiah Kajian Pendidikan dan Kebudayaan No. 008/II/Maret, Badan Penelitian dan Pengembangan Pendidikan dan Kebudayaan, 1997, h. 44-56.

17 Ali Imron, Pembinaan Guru di Indonesia, (Jakarta: Pustaka Jaya, 1995), h. 183.

18 Panji Anoraga, Psikologi Kerja, h. 52.

220| Al Amin:Jurnal Kajian Ilmu dan Budaya Islam, Volume 1, No 2, 2018 


\section{Syarifuddin}

meninggalkan profesi guru dan sekolah sebagai tempat mereka bekerja. Akibatnya, ia akan selalu mengembangkan karier untuk mencapai kemajuan.

\section{Ciri-ciri atau Sifat Mengenai Cara Bekerja}

Toto Tasmara dalam Membudayakan Etos Kerja Islami mengatakan 'Ciri-ciri orang-orang yang mempunyai dan menghayati etos kerja akan tampak dalam sikap dan tingkah lakunya yang dilandaskan pada suatu keyakinan yang sangat mendalam bahwa bekerja itu ibadah dan berprestasi itu indah.' Ada semacam panggilan dari hatinya untuk terus menerus memperbaiki diri, mencari prestasi bukan prestise, dan tampil sebagai bagian dari umat yang terbaik (khairu ummah). Secara metaforis, bahkan dapat saya katakan bahwa seorang muslim itu sangat kecanduan untuk beramal saleh. Jiwanya gelisah apabila dirinya hampa, tidak segera berbuat kesalehan. Ada semacam dorongan yang sangat luar biasa untuk memenuhi hasrat memuaskan dahaga jiwanya yang hanya terpenuhi apabila dia berbuat kesalehan tersebut. ${ }^{19}$

Menurut penulis, orang-orang yang mempunyai ciriciri seperti yang dimaksud oleh Toto Tasmara di atas sangatlah sedikit jumlahnya. Bahkan boleh dikata hampir tidak ada. Kalaupun ada mungkin akan habis dibilang dengan hitungan jari tangan. Adapun ciri-ciri orang yang mempunyai dan menghayati etos kerja menurut Toto Tasmara dalam membudayakan etos kerja Islami akan tampak dalam sikap dan tingkah laku berikut:

a. Mereka kecanduan terhadap waktu

Salah satu esensi dan hakikat dari etos kerja adalah cara seseorang menghayati, memahami, dan merasakan betapa berharganya waktu.

b. Mereka memiliki moralitas yang bersih (ikhlas)

Salah satu kompetensi moral yang dimiliki oleh seseorang yang berbudaya kerja Islami adalah nilai keikhlasan. Mereka yang mempunyai jiwa yang ikhlas akan melaksanakan tugasnya secara profesional tanpa motivasi lain kecuali bahwa pekerjaan itu merupakan amanat yang harus ditunaikannya sebaik-baiknya dan

19 Toto Tasmara, Membudayakan Etos Kerja Islami, h. 73.

Al Amin: Jurnal Kajian Ilmu dan Budaya Islam, Volume 1, No 2, 2018| 221 
memang begitulah seharusnya. Motivasi unggul yang ada hanyalah pamrih pada hati nuraninya sendiri (conscience). Kalaupun ada reward atau imbalan, itu bukanlah tujuan utama, melainkan sekadar akibat sampingan (side effect) dari pengabdian dirinya yang murni tersebut.

c. Mereka kecanduan kejujuran

Perilaku yang jujur adalah perilaku yang diikuti oleh sikap tanggungjawab atas apa yang diperbuatnya tersebut atau integritas. Kejujuran dan integritas ini bagaikan dua sisi mata uang. Seseorang tidak cukup hanya memiliki keikhlasan dan kejujuran, tetapi dibutuhkan nilai pendorong lainnya, yaitu integritas. Akibatnya, mereka siap menghadapi risiko dan seluruh akibatnya dia hadapi dengan gagah berani, kebanggaan, dan penuh suka cita, dan tidak pernah terpikir olehnya untuk melemparkan tanggung jawabnya kepada orang lain.

d. Mereka memiliki komitmen

Yang dimaksud dengan komitmen adalah keyakinan yang mengikat sedemikian kukuhnya sehingga membelenggu seluruh hati nuraninya dan kemudian menggerakkan perilaku menuju arah tertentu yang diyakini. Dalam komitmen tergantung sebuah tekad, keyakinan, yang melahirkan bentuk vitalitas yang penuh gairah. Mereka yang memiliki komitmen tidak mengenal kata menyerah, karenanya, mereka hanya akan berhenti menapaki cita-citanya bila langit sudah runtuh. Bagi mereka, komitmen adalah soal tindakan, keberanian, kesungguhan, dan kesinambungan.

e. Istiqāmah, kuat pendirian

Istiqāmah berarti berhadapan dengan segala rintangan masih tetap qiyām (berdiri). Konsisten berarti tetap menapaki jalan lurus walaupun sejuta rintangan menerjang, sejuta halangan menghadang, dan sejuta hambatan melintang mereka tetap tegar dalam pendirian. Seseorang yang istiqāmah tidak mudah berbelok arah, betapapun godaan untuk mengubah tujuan begitu memikatnya, dia tetap pada niat semula.

f. Mereka kecanduan disiplin 


\section{Syarifuddin}

Erat kaitannya dengan konsisten adalah sikap berdisiplin, yaitu suatu sikap, perbuatan untuk selalu mentaati tata tertib. Pribadi yang berdisiplin sangat berhati-hati dalam mengelola pekerjaan serta penuh tanggung jawab memenuhi kewajibannya. Mata hati dan profesi terarah pada hasil yang akan diraih sehingga mampu menyesuaikan diri dalam situasi yang menantang. Mereka pun mempunyai daya adaptabilitas atau keluwesan untuk menerima inovasi atau gagasan baru. Daya adaptabilitasnya sangat luwes dalam cara dirinya menangani berbagai perubahan yang menekan. Karena sikapnya yang konsisten itu pula, mereka tidak tertutup pada gagasan-gagasan baru yang bersifat inovatif.

g. Konsekuen dan berani menghadapi tantangan

Ciri lain dari pribadi yang memiliki budaya kerja adalah keberaniannya menerima konsekuensi dari keputusannya. Bagi mereka, hidup adalah pilihan, dan setiap pilihan merupakan tanggung jawab pribadinya. Mereka tidak mungkin menyalahkan pihak mana pun, karena pada akhirnya semua pilihan ditetapkan oleh dirinya sendiri. Rasa tanggung jawabnya mendorong perilakunya yang bergerak dinamis, seakan-akan di dalam dadanya ada 'nyala api', sebuah motivasi yang kuat untuk mencapai tujuan dan menjaga apa yang telah menjadi keputusan atau pilihannya.

h. Mereka memiliki sikap dan percaya diri

Percaya diri melahirkan kekuatan, keberanian, dan ketegasan dalam bersikap. Berani mengambil keputusan yang sulit walaupun harus membawa konsekuensi berupa tantangan atau penolakan.

i. Mereka orang yang kreatif

Pribadi muslim yang kreatif selalu ingin mencoba metode atau gagasan baru sehingga diharapkan hasil kinerja dapat dilaksanakan secara efektif dan efisien.

j. Mereka tipe orang yang bertanggungjawab

Tindakan bertanggungjawab dapat didefinisikan sebagai sikap dan tindakan seseorang di dalam menerima sesuatu sebagai amanat; dengan penuh rasa cinta, ia ingin menunaikannya dalam bentuk pilihanpilihan yang melahirkan amal prestatif. Mereka yang 
memiliki tanggung jawab ini memersepsikan pekerjaannya sebagai amanat yang harus ditunaikan dengan penuh kesungguhan, yang kemudian melahirkan keyakinan yang mendalam bahwa bekerja itu ibadah dan berprestasi itu indah.

k. Mereka bahagia karena melayani

Mereka melayani dengan cinta, bukan karena tugas atau pengaruh dari luar, melainkan benar-benar sebuah obsesi yang sangat mendalam bahwa "aku bahagia karena melayani"

1. Mereka memiliki harga diri

Seseorang yang memiliki harga diri akan selalu berbinar ketika dia ingin menyebarkan nilai manfaat. Hidupnya penuh gairah untuk menjadikan dirinya sebagai sosok manusia yang senantiasa memberikan pelayanan kepada orang lain dengan penuh cinta, dan itu mahal harganya.

m. Mereka memiliki jiwa kepemimpinan

Sebagai seorang mujahid yang dituntut untuk memiliki jiwa kepemimpinan, sudah barang tentu seluruh peranan dirinya merupakan bayang-bayang dari hukum dan kehendak Allah, sehingga keputusan dan kehadiran dirinya mampu mempengaruhi orang lain, lingkungan, dan ruang serta waktu dengan butiran nilai tauhid. Kepemimpinan berarti kemampuan untuk mengambil posisi dan sekaligus memainkan peran (role) sehingga kehadiran dirinya mampu memberikan pengaruh kepada lingkungannya. Seorang pemimpin adalah seorang yang mempunyai personalitas yang tinggi. Dia larut dalam keyakinannya, tetapi tidak segan untuk menerima kritik, bahkan mengikuti apa yang terbaik. Seorang pemimpin bukan tipikal pengekor, terima jadi, karena sebagai seorang pemimpin, dia sudah dilatih untuk berpikir kritis analitis, karena dia sadar bahwa seluruh hidupnya akan dimintai pertanggungjawaban di hadapan Allah, sebagaimana firman-Nya.

"Dan janganlah kamu mengikuti apa yang kamu
tidak mempunyai pengetahuan tentangnya.
Sesungguhnya pendengaran, penglihatan, dan hati, 


\section{Syarifuddin}

semuanya itu akan diminta pertanggungjawabannya," (QS. al-Isrā' [17]: 36). ${ }^{20}$

Pribadi muslim yang memiliki etos kerja mempuyai pandangan jauh ke depan. Gagasan pikirannya melampaui zamannya sehingga mereka pantas disebut pemimpin yang memiliki pandangan atau wawasan ke depan (visionary leadership). Mereka memiliki daya aktivitas yang sangat kuat, menghargai orang lain, dan terbuka terhadap gagasan bahkan kritik.

n. Mereka berorientasi ke masa depan

Seorang pribadi yang memiliki etos kerja tidak akan berspekulasi dengan masa depan dirinya. Dia selalu menetapkan segala sesuatunya dengan jelas sehingga seluruh tindakannya diarahkan pada tujuan yang telah ditetapkan.

o. Hidup berhemat dan efisien

Dia berhemat bukan karena ingin memupuk kekayaan sehingga melahirkan sifat kikir individualistis, melainkan karena ada satu reserve bahwa tidak selamanya waktu itu berjalan lurus, ada up dan down, sehingga berhemat berarti mengestimasikan apa yang akan terjadi di masa yang akan datang. Efisiensi berarti melakukan segala sesuatu secara benar, tepat, dan akurat. Efisien berarti pula mampu membandingkan antara besaran output dan input. Adapun efektivitas berkaitan dengan tujuan atau menetapkan hal yang benar. ${ }^{21}$

Dengan demikian, bisa dikatakan bahwa efisiensi berarti berkaitan dengan cara melaksanakan, sedangkan efektivitas berkaitan dengan arah tujuan.

p. Memiliki jiwa wiraswasta yang tinggi

Orang yang memiliki etos kerja harus memiliki jiwa wiraswasta yang tinggi, yaitu kesadaran dan kemampuan yang sangat mendalam untuk melihat segala fenomena yang ada di sekitarnya, merenung dan kemudian bergelora semangatnya untuk mewujudkan

20 Yayasan Penyelenggara Penerjemah al-Qur`an, Al-Qur`an dan Terjemahnya, h. 429.

21 Toto Tasmara, Membudayakan Etos Kerja Islami, h. 105106.

Al Amin: Jurnal Kajian Ilmu dan Budaya Islam, Volume 1, No 2, 2018| 225 
setiap perenungan batinnya dalam bentuk yang nyata dan realistis. Karena itu, mereka selalu melihat setiap sudut kehidupan dunia sebagai peluang kesempatan yang harus dicoba.

q. Memiliki insting bertanding (fastabiq al-khairāt)

Semangat bertanding merupakan sisi lain dari seorang muslim yang memiliki etos kerja. Panggilan untuk bertanding dalam segala lapangan kebajikan dan meraih prestasi, dihayatinya dengan rasa penuh tanggung jawab sebagai pembuktian ayat al-Qur`an yang telah menggoreskan kalamnya dengan sangat motivatif, sebagaimana firman-Nya.

"Setiap umat ada kiblatnya (sendiri), maka hendaklah kamu sekalian berlomba-lomba (dalam kebaikan)," (al-Baqarah [2]: 148). ${ }^{22}$

Mana mungkin seseorang bisa berlomba atau bertanding apabila tidak ada gairah untuk bekerja, bergerak, dan berjuang. Untuk itu, dia tidak akan pernah menyerah pada kelemahan atau pengertian nasib dalam artian sebagai seorang fatalis.

r. Keinginan untuk mandiri (independent)

Seseorang yang mempunyai etos kerja merasa bahagia bila dapat memperoleh hasil atas usaha, karsa, dan karya yang dibuahkan dari dirinya sendiri. Karena itu, ia mempunyai keinginan yang kuat untuk mandiri.

s. Mereka kecanduan belajar dan haus mencari ilmu

Kecanduan belajar dan kehausan mencari ilmu ini didasari oleh kesadaran bahwa Rasulullah mewajibkan pada setiap umatnya untuk mencari ilmu dari buaian hingga ke liang lahat. Bahkan demi ilmu, dia tidak peduli sejauh mana tempat yang harus ia tempuh, walau ke negeri China. Sifat kritis dan objektivitasnya pun menyebabkan ia tidak melihat 'siapa' yang mengatakan, selama yang dikatakannya adalah ilmu dan kebenaran, dia akan timba dan resapi.

t. Memiliki semangat perantauan

22 Yayasan Penyelenggara Penerjemah al-Qur`an, Al-Qur`an dan Terjemahnya, h. 38.

226| Al Amin:Jurnal Kajian Ilmu dan Budaya Islam, Volume 1, No 2, 2018 


\section{Syarifuddin}

Salah satu ciri pribadi yang memiliki etos kerja adalah suatu dorongan untuk melakukan perantauan. Mereka ingin menjelajahi seluruh hamparan bumi, memetik hikmah, dan mengambil pelajaran dari berbagai peristiwa budaya manusia. Tetapi, semangat perantauan tidak selamanya dibuktikan secara fisik. Ada juga perantauan bathin yang dia peroleh dari hasil membaca buku, menggali hikmah dan menyimak fenomena alam. Badannya tidak pergi jauh, tetapi daya imajinasinya merantau sampai ke luar batas langit, dan kemudian melahirkan berbagai gagasan kreatif.

u. Memperhatikan kesehatan dan gizi

Etos kerja muslim adalah etos yang sangat erat kaitannya dengan cara dirinya memelihara kebugaran dan kesegaran jasmaninya.

v. Tangguh dan pantang menyerah

Ketangguhan dan keuletan merupakan modal yang sangat besar dalam menghadapi tantangan atau tekanan (pressure), sebab sejarah telah banyak membuktikan betapa banyak bangsa yang mempunyai sejarah pahit, namun akhirnya dapat keluar dengan berbagai inovasi, kohesifitas kelompok, dan mampu memberikan prestasi yang tinggi bagi lingkungannya. Karena itulah, bisa dikatakan bahwa kerja keras, ulet, tangguh, dan pantang menyerah merupakan ciri dan cara dari kepribadian muslim yang memiliki etos kerja.

w. Berorientasi pada produktivitas

Seorang Muslim itu seharusnya sangat menghayati makna yang difirmankan Allah dengan sangat tegas, yaitu larangan untuk bersikap mubazir karena sesungguhnya orang-orang yang berbuat mubazir adalah temannya setan.

x. Memperkaya jaringan silaturahmi

Pribadi yang memiliki etos kerja akan menjadikan silaturahmi sebagai salah satu ruh pengembangan dirinya. Karena bukan saja memiliki nilai ibadah, tetapi hasilnya juga dapat dipetik di dunia, yaitu memberikan satu alur informasi yang dapat membuka peluang dan kesempatan usaha.

y. Mereka memiliki semangat perubahan 
Pribadi yang memiliki etos kerja sangat sadar bahwa tidak ada satu makhluk pun di bumi ini yang mampu mengubah dirinya kecuali dirinya sendiri. Hal ini sesuai dengan firman Allah Swt:

"Sesungguhnya Allah tidak akan mengubah suatu kaum kecuali kaum itu sendiri yang mengubah keadaan diri mereka sendiri," (al-Ra'd [13]: 11). ${ }^{23}$

Ayat ini mengajak seseorang untuk memainkan peranan, mengubah nasib, dan menempatkan diri dalam posisi yang tentu saja menjadi lebih baik, dan lebih baik lagi.

\section{Etos Kerja Guru}

Keadaan etos kerja seseorang setidak-tidaknya dapat dibidik dari cara kerjanya yang memiliki 3 ciri dasar, yaitu (1) keinginan untuk menjunjung tinggi mutu pekerjaan (job quality); (2) menjaga harga diri dalam melaksanakan pekerjaan; dan (3) keinginan untuk memberikan layanan kepada masyarakat melalui karya profesionalnya. ${ }^{24}$

Keempat ciri dasar tersebut pada dasarnya terkait dengan kualifikasi yang harus dimiliki oleh guru pada umumnya, yaitu kualifikasi akademik, profesional, personal, dan sosial.

Dalam pola pemahaman sistem tenaga kependidikan di Indonesia, terdapat empat dimensi umum kompetensi yang saling menunjang dalam membentuk kompetensi profesional tenaga kependidikan, yaitu (1); Kompetensi akademik; (2) Kompetensi profesional (3) Kompetensi personal; dan (4) Kompetensi sosial. Dilihat dari sisi ini, maka ciri dasar yang pertama tersebut di atas terkait dengan kompetensi akademik, yakni kemampuan guru dalam mengorganisasikan bahan ajar yang akan diberikan kepada anak didiknya, pengorganisasian alokasi waktu yang akan digunakannya, pengorganisasian metode dan model pembelajarannya, pengorganisasian proses Kegiatan Belajar Mengajar (KBM), pengorganisasian kelas, sampai pada akhirnya melakukan tes dan evaluasi keberhasilan dalam

23 Yayasan Penyelenggara Penerjemah al-Qur`an, Al-Qur`an dan Terjemahnya, h. 370.

24 Mochtar Bukhori, Pendidikan Dalam Pembangunan, h. 41.

228| Al Amin:Jurnal Kajian Ilmu dan Budaya Islam, Volume 1, No 2, 2018 


\section{Syarifuddin}

kegiatan akademik yang harus dipenuhinya. Ciri dasar kedua profesional, yakni menyangkut kemampuan dan kesediaan serta tekad seorang guru untuk mewujudkan tujuan-tujuan pendidikan yang telah dirancang melalui proses dan produk kerja yang bermutu. Ciri dasar yang ketiga, terkait dengan kompetensi personal, yakni ciri hakiki dari kepribadian seorang guru untuk menjaga harga diri dalam melaksanakan pekerjaannya guna mencapai tujuan pendidikan yang telah ditetapkan. Ciri dasar keempat terkait dengan kompetensi sosial, yakni perilaku seorang guru yang berkeinginan dan bersedia memberikan layanan kepada masyarakat melalui karya profesionalnya untuk mencapai tujuan pendidikan. Al-Ghazali, seorang ulama terkenal telah memformulasikan ciri-ciri dan sifat-sifat guru yang diharapkan berhasil dalam menjalankan tugas-tugas kependidikannya. Berbagai sifat dan ciri-ciri tersebut sekaligus mencerminkan etos kerja guru yang diharapkan (ideal). ${ }^{25}$

Adapun sifat-sifat dan ciri-ciri tersebut adalah:

1. Kasih sayang kepada peserta didik dan memperlakukannya sebagaimana anak sendiri.

2. Meneladani Rasulullah sehingga jangan menuntut upah, imbalan, dan penghargaan.

3. Hendaknya tidak memberi predikat/martabat kepada peserta didik sebelum ia pantas/kompeten untuk menyandangnya, dan jangan memberi ilmu yang samar (al-'ilm al-khäfy) sebelum tuntas ilmu jelas (al-'ilm al-jaly).

4. Hendaknya mencegah peserta didik dari akhlak yang jelek (sedapat mungkin) dengan cara sindiran dan tidak tunjuk hidung

5. Guru yang memegang bidang studi tertentu hendaknya tidak meremehkan atau menjelek-jelekkan bidang studi yang lain.

6. Menyajikan pelajaran kepada peserta didik sesuai dengan taraf kemampuan mereka.

7. Dalam menghadapi peserta didik yang kurang mampu hendaknya diberikan ilmu-ilmu yang global dan tidak perlu menyajikan detailnya.

25 Badawi Thobanah, Ihyā' 'Ulūmuddīn Li al-Imām al-Ghazāli, (Semarang: Maktabah Usaha Keluarga, 1989), h. 55-58. 
8. Guru hendaknya mengamalkan ilmunya, dan jangan sampai ucapannya bertentangan dengan perbuatannya.

Mengenai rumusan guru yang baik Dahama dan Bhatnagar dalam Education and Communication for Development mengatakan bahwa:

Attributes of a good teacher are: 1). Knowledge and understanding of his subject. 2). Enthusiasm about his subject. 3). Interest in students. 4). Have a knowledge of teaching skills. 5). Broad interests and an engaging personality. 6). Demanding that each student put forth his best effort. 7). Encourages and motivates. ${ }^{26}$

Dalam konteks pendidikan di sekolah, rumusan alGhazali serta Dahama dan Bhatnagar tersebut dapat dijadikan sebagai alat untuk memahami etos kerja seorang guru. Hanya saja, dalam konteks masa kini dan masa depan, yang masyarakatnya memiliki tiga karakteristik, yaitu masyarakat teknologi, masyarakat terbuka, dan masyarakat madani, etos kerja seorang guru sudah barang tentu tidak hanya berorientasi pada peningkatan kualitas dimensi personal dan sosial, tetapi juga perlu adanya keseimbangan dengan peningkatan kualitas intelektual dan profesionalnya. Karena itu, perlu adanya keseimbangan antara orientasi pendidikan yang menuntut kesalehan individu dan sosial dengan kesalehan intelektual dan profesional.

Kesalehan intelektual dan profesional dari guru pada umumnya ditandai dengan beberapa karakteristik sebagai berikut:

a. Memiliki kepribadian yang matang dan berkembang;

b. Menguasai ilmu pengetahuan dan teknologi (bidang keahliannya) serta wawasan pengembangannya;

c. Menguasai keterampilan untuk membangkitkan minat siswa kepada ilmu pengetahuan;

d. Siap untuk mengembangkan profesi secara berkesinambungan, agar ilmu dan keahliannya tidak cepat tua atau out of date. Sebagai implikasinya, seorang guru akan selalu concern dan komitmen dalam

26 Dahama dan Bhatnagar, Education and Communication for Development, (New Delhi: Oxford \& IBH Publishing Co, 1980), h. 8283.

230| Al Amin:Jurnal Kajian Ilmu dan Budaya Islam, Volume 1, No 2, 2018 


\section{Syarifuddin}

peningkatan studi lanjut, mengikuti kegiatan-kegiatan diskusi, seminar, pelatihan, dan lain-lainnya. ${ }^{27}$

Berbagai uraian di atas menggambarkan keadaan etos kerja guru yang tinggi. Sebaliknya, terdapat prototipe guru yang keadaan etos kerjanya rendah. Hasil penelitian Wiles (1955) yang dikutip oleh Sahertian menyebutkan sejumlah prototype guru di sekolah, antara lain (1) Guru yang malas; (2) Guru yang pudar; (3) Guru tua; (4) Guru yang kurang demokratis; dan (5) Guru yang suka menentang. ${ }^{28}$

Menurut hasil penelitian Wiles tersebut, guru yang malas kebanyakan bersumber pada gaji yang tidak cukup, kemudian ia mencari pekerjaan tambahan di luar untuk memenuhi kebutuhan tiap bulan. Akibatnya, etos kerjanya sebagai guru di sekolah semakin menurun. Guru yang pudar adalah guru yang jarang tersenyum, kurang humor, kurang ramah, sukar bergaul dengan orang lain, dan sebagainya.

Guru tua adalah guru yang sudah terlalu lama dinas, sehingga sukar diubah. Biasanya mereka kurang percaya diri dan merasa tersaingi dengan tampilnya guru-guru muda. Oleh karena itu, ia menunjukkan diri seolah-olah tinggi, padahal ia sendiri tidak ingin lagi mengembangkan dirinya agar terus bertumbuh dalam jabatannya. Guru yang kurang demokratis, yakni orang yang sudah terlalu lama bekerja yang biasanya terlalu memusatkan perhatian pada kepuasan dirinya sendiri. Rasa harga dirinya sendiri terlalu tinggi sehingga memperlakukan diri melebihi batas kebebasan orang lain, ia bersifat tidak demokratis. Guru yang suka menentang, yakni guru yang sangat kritis, sehingga ia berfikir kritis dan selalu suka mengkritik orang lain. Suka mengkritik sudah merupakan suatu kebiasaan (habit).

Kecenderungan ini tidak selalu baik bila berhadapan, baik bila dengan guru lain maupun dengan siswa karena bisa jadi menjatuhkan mental dan semangat belajar mereka untuk aktualisasi diri. Sejumlah prototipe guru tersebut barangkali dapat dipakai sebagai kerangka teoretis untuk memahami keadaan etos kerja seorang guru di sekolahsekolah, terutama dalam konteks etos kerja yang rendah.

27 H. A. R. Tilaar, Beberapa Agenda Reformasi Pendidikan Nasional dalam Perspektif Abad 21, (Magelang: Tera Indonesia, 2000), h. 295.

28 Piet. A. Sahertian, Profil Pendidik Profesional, (Yogyakarta: Andi Offset, 1994), h. 60. 


\section{E. Faktor-faktor Yang Mempengaruhi Etos Kerja Guru}

Seseorang agaknya akan sulit melaksanakan tugas/pekerjaannya dengan tekun dan memiliki komitmen terhadap ketiga ciri dasar yang telah tersebut di atas, jika pekerjaan itu kurang bermakna baginya, dan tidak bersangkutan dengan tujuan hidupnya yang lebih tinggi, langsung ataupun tidak langsung. Cara kerja seseorang yang memandang pekerjaannya sebagai kegiatan untuk mencari nafkah semata atau hanya untuk memperoleh gaji (salary) dan sandang pangan demi survival fisik jangka pendek, agaknya akan berbeda dengan cara kerja seseorang yang memandang tugas/pekerjaanya sebagai calling profession dan amanat yang hendak dipertanggungjawabkan di hadapan Tuhan. Munculnya sikap malas, santai, dan tidak disiplin waktu dalam bekerja dapat bersumber dari pandangannya terhadap pekerjaan dan tujuan hidupnya. Karena itu, adanya etos kerja yang kuat pada seseorang memerlukan kesadaran mengenai kaitan suatu pekerjaan dengan pandangan hidupnya yang lebih menyeluruh, dan yang memberinya keinsafan akan makna dan tujuan hidupnya. ${ }^{29}$

Etos kerja juga sangat erat kaitannya dengan sistem pendidikan dan budaya yang ada di lingkungan seseorang. ${ }^{30}$ Contoh nilai-nilai keyakinan, budaya, dan beberapa kebiasaan yang dapat menghambat etos kerja seseorang adalah (1) Khurafat dan takhayul, (2) Tak akan lari gunung dikejar; alon-alon asal kelakon, (3) Gampangan, take it easy, bagaimana nanti sajalah, (4) Mangan ora mangan pokoke kumpul, (5) Nrima-Fatalistis, (6) Salah persepsi, bahwa kerja kasar itu hina, dan (7) Keyakinan akan keampuhan suatu jimat atau mascot. ${ }^{31}$

Paham fatalisme (menyerahkan semuanya kepada Tuhan) juga telah mempengaruhi etos kerja umat Islam. bahkan, muncul pula paham tasawuf yang dipinggirkan pengertiannya dari makna zuhud yang sebenarnya. Zuhud menjadi 'meninggalkan dunia dengan segala keindahan dan

29 Muhaimin, et. all., Paradigma Pendidikan Islam: Upaya Mengefektifkan Pendidikan Agama Islam di Sekolah, (Bandung: PT. Remaja Rosdakarya, 2001), h. 118.

30 Toto Tasmara, Etos Kerja Pribadi Muslim, h. 125.

31 Toto Tasmara, Etos Kerja Pribadi Muslim, h. 125-132. 


\section{Syarifuddin}

kelezatannya, lalu mengonsentrasikan beribadah'. Dalam kondisi yang demikian, terjadi kemerosotan etos kerja. ${ }^{32}$

Jadi jika seseorang menganut paham fatalisme (menyerahkan semuanya kepada Tuhan) dapat menyebabkan etos kerjanya menjadi lemah. Demikian juga jika seseorang menganut paham tasawuf yang memandang zuhud menjadi meninggalkan dunia dengan segala keindahan dan kelezatannya demi mengonsentrasikan beribadah tentu etos kerja seseorang itu jadi lemah. Uraian di atas menggarisbawahi adanya faktor internal, antara lain sistem kepercayaan yang menjadi pandangan hidup seseorang, yang sering kali mempengaruhi dan ikut membentuk etos kerja seseorang, sehingga latar belakang terbentuknya etos kerja seorang guru, antara lain dapat dipantau dari sudut pandang tersebut. Hanya saja, suatu kenyataan empiris biasanya tidak selalu berdiri sendiri dan bersifat linier, akan tetapi merupakan akibat dari beberapa faktor. Penjelasan tentang terbentuknya etos kerja seseorang (termasuk guru) juga tidak dapat hanya dilihat dari satu sudut pandang, seperti sistem kepercayaan sebagaimana uraian tersebut di atas, karena bisa jadi faktor tersebut tidak mendukungnya, justru terdapat faktor-faktor lain yang lebih dominan.

Patutlah disimak beberapa pendapat para pakar berikut ini, antara lain A. Mukti Ali yang menyatakan bahwa ada tiga hal yang ikut membentuk watak karakter dan tindak laku seseorang, yaitu sistem budaya dan agama; sistem sosial; dan lingkungan alam dimana orang itu hidup. ${ }^{33}$

Lain lagi dengan pendapat M. Dawam Rahardjo yang menyatakan bahwa etos kerja tidak semata-mata bergantung pada nilai-nilai agama dalam arti sempit, tetapi dewasa ini sangat dipengaruhi oleh pendidikan, informasi, dan komunikasi. Oleh sebab itu, yang perlu dikembangkan adalah etos kerja ilmu pengetahuan dan komunikasi. ${ }^{34}$

Dari kedua pendapat tersebut tampaknya terdapat titik temu dalam menjelaskan faktor-faktor yang mempengaruhi

32 Rusydi AM., "Etos Kerja dan Etika Usaha: Perspektif AlQur`an" dalam Firdaus Effendi, dkk (ed), "Nilai dan Makna Kerja dalam Islam", (Jakarta: Nuansa Madani, 1990), h. 98.

33 A. Mukti Ali, Beberapa Persoalan Agama Dewasa Ini, (Jakarta: Rajawali Press, 1987), h. 172.

34 M. Dawam Rahardjo, Intelektual, Intelegensia, dan Perilaku Politik Bangsa: Risalah Cendekiawan Muslim, (Bandung: Mizan, 1996), h. 463. 
etos kerja seseorang. Jika dikaitkan dengan etos kerja guru di sekolah, maka ada dua aspek esensial dalam menjelaskan faktor-faktor tersebut, yaitu (1) faktor pertimbangan internal, yang menyangkut ajaran yang diyakini atau sistem budaya, agama, dan kepercayaan, serta semangat untuk menggali informasi dan menjalin komunikasi; dan (2) faktor pertimbangan eksternal, yang menyangkut latar belakang pendidikan, sistem sosial dimana seseorang itu hidup, dan lingkungan alam yang lainnya, seperti lingkungan kerja seseorang. Dalam konteks pertimbangan eksternal, terutama yang menyangkut lingkungan kerja, secara lebih terinci HM. Arifin menyatakan bahwa ada beberapa hal yang mempengaruhi semangat kerja, yaitu:

1. Volume upah kerja yang dapat memenuhi kebutuhan seseorang.

2. Suasana kerja yang menggairahkan atau iklim yang ditunjang dengan komunikasi demokrasi yang sesuai dan manusiawi antara pimpinan dan bawahan.

3. Penanaman sikap dan pengertian di kalangan pekerja.

4. Sikap jujur dan dapat dipercaya dari kalangan pimpinan harus benar-benar dapat diwujudkan dalam kenyataan.

5. Penghargaan terhadap need for achievement (hasrat dan kebutuhan untuk maju) atau penghargaan terhadap yang berprestasi.

6. Sarana yang menunjang bagi kesejahteraan mental dan fisik, seperti tempat olah raga, masjid, rekreasi, hiburan, dan lain-lain. ${ }^{35}$

Made Wahyu Sutedja juga berpendapat bahwa usaha untuk membangun etos kerja staf pengajar (guru) dapat dilakukan melalui:

a. Terpeliharanya rasa hidup aman dan menyenangkan;

b. Terpeliharanya kondisi kerja yang menyenangkan;

c. Terpeliharanya rasa tergolong;

d. Terpeliharanya rasa mendapatkan perlakuan yang fair;

e. Terpeliharanya rasa mencapai:

1) Terpeliharanya rasa mampu mengerjakan tugas.

2) Terpeliharanya rasa dapat memberikan sumbangan yang nyata.

35 M. Arifin, Kapita Selekta Pendidikan (Islam dan Umum), Jakarta: Bumi Aksara, 2000, h. 283-284.

234| Al Amin: Jurnal Kajian Ilmu dan Budaya Islam, Volume 1, No 2, 2018 


\section{Syarifuddin}

3) Terpeliharanya rasa maju dalam pekerjaan.

4) Terpeliharanya rasa bertumbuh, dan lain-lain. ${ }^{36}$

Guru-guru menghendaki kehidupan yang aman dan menyenangkan. Hidup menyenangkan bukan berarti mewah (lux) melainkan mendekati standar hidup. Orang sebetulnya ingin mampu memiliki makanan, pakaian, keteduhan bagi keluarganya, merasa bebas dari ketakutan finansial, juga ingin makan enak, walaupun itu terjadi hanya untuk sekali waktu. Untuk itulah seorang pemimpin di bidang pendidikan hendaknya memikirkan bagaimana dapat menggaji guru secara memadai agar mereka dapat hidup dalam kondisi aman dan menyenangkan.

Di samping itu, guru-guru juga menghendaki pekerjaan dengan kondisi yang menyenangkan. Bagi kebanyakan orang, faktor-faktor yang dituntut untuk menjadikan suatu pekerjaan jadi menyenangkan berbeda dan bervariasi, tetapi secara umum dapat disebutkan beberapa, antara lain: lingkungan yang menarik, bersih, lengkap dengan peralatan yang modern, kesejahteraan pegawai yang diperhatikan, dan berjalan atas hal-hal yang manajerial, juga yang diingini. ${ }^{37}$

Terpeliharanya rasa tergolong juga penting untuk membangun etos kerja staf pengajar. Rasa tergolong yang dimaksud adalah rasa tergolong dalam suatu kelompok dimana mereka melaksanakan tugasnya. Keinginan untuk diterima kelompok serta tetap tinggal di dalamnya merupakan sesuatu hal yang dapat mendorong kegairahan kerja, dibandingkan dengan jika mereka berada di luar kelompok. Setiap orang normal tetap ingin diterima oleh kelompoknya. Bagaimana hal ini dapat diwujudkan dalam rangka membangun etos kerja staf pengajar (guru)?

Untuk mewujudkan hal ini, misalnya:

a) Menciptakan dan mengikutsertakan dalam kegiatankegiatan sosial di sekolah, misalnya menjadi panitia ini dan itu, dan sebagainya.

b) Mengikutsertakan dalam mengerjakan buku-buku personalia.

36 Made Wahyu Suthedja, Bagaimana Membangun Semangat Staf Pengajar, (Semarang: Satya Wacana, 1988), h. 14-15.

37 Made Wahyu Suthedja, Bagaimana Membangun Semangat Staf Pengajar, h. 11.

Al Amin: Jurnal Kajian Ilmu dan Budaya Islam, Volume 1, No 2, 2018| 235 
c) Mengikutsertakan dalam proyek-proyek, misalnya dalam proyek uji coba, proyek memperindah halaman dan sebagainya. Semua hal yang disebut di atas dapat membantu guru-guru untuk menumbuhkan rasa tergolong (feeling of belonging).

\section{F. Kesimpulan}

Dalam usaha membangun etos kerja guru adalah terpeliharanya rasa mendapatkan perlakuan yang fair: Jujur, sehat, adil, dan sebagainya. Satu hal lagi yang tidak boleh dilupakan dalam membangun etos kerja guru adalah terpeliharanya rasa mencapai. Guru-guru tersebut menghendaki memiliki rasa mencapai karena mereka ingin tahu bahwa mereka adalah orang-orang yang kompeten, ini berarti bahwa mereka merasa membuat sumbangan yang besar bagi suatu kegiatan, misalnya berkat melalui mereka terjadi kemajuan-kemajuan besar sehingga mereka merasa bertumbuh dalam pekerjaannya. Untuk ini dapat diperinci sebagai berikut:

1. Mereka ingin merasa mampu mengerjakan tugastugasnya.

2. Guru-guru menghendaki untuk merasakan bahwa mereka membuat suatu sumbangan yang nyata bagi masyarakat melalui pekerjaannya.

3. Guru-guru menginginkan untuk merasa maju dalam pekerjaannya.

4. Guru-guru menghendaki adanya rasa bertumbuh.

Mengenai rasa bertumbuh ini ada tiga macam, yaitu: adanya perasaan dipentingkan, adanya rasa mendapat kesempatan untuk ikut merumuskan kebijakan dan adanya kesempatan untuk memelihara kehormatan diri sendiri. 


\section{Syarifuddin}

\section{DAFTAR PUSTAKA}

A. Mukti Ali, Beberapa Persoalan Agama Dewasa Ini, Jakarta: Rajawali Press, 1987.

Abdul Aziz al-Khayyat, Nazrah al-Islām Li al-'Āmah Wa Aśaruhu Fì al-Tanmiyah, atau Etika Bekerja dalam Islam, terj. Moh. Nurhakim, Jakarta: Gema Insani Press, 1994.

Abdul Rozak, dkk, Etos Kerja Mendorong Produktivitas Umat Beragama di Abad Dua Satu, Jakarta: Zikrul Hakim, 1997.

Ali Imron, Pembinaan Guru di Indonesia, Jakarta: Pustaka Jaya, 1995.

Ali Sumanto al-Khindhi, Bekerja sebagai Ibadah: Konsep Memberantas Kemiskinan, Kebodohan, dan Keterbelakangan Umat, Solo: CV. Aneka, 1997.

Badawi Thobanah, Ihyā' 'Ulūmuddīn Li al-Imām al-Ghazāli, Semarang: Maktabah Usaha Keluarga, 1989.

Dahama dan Bhatnagar, Education and Communication for Development, New Delhi: Oxford \& IBH Publishing Co, 1980.

H. A. R. Tilaar, Beberapa Agenda Reformasi Pendidikan Nasional dalam Perspektif Abad 21, Magelang: Tera Indonesia, 2000.

M. Arifin, Kapita Selekta Pendidikan (Islam dan Umum), Jakarta: Bumi Aksara, 2000.

M. Dawam Rahardjo, Intelektual, Intelegensia, dan Perilaku Politik Bangsa: Risalah Cendekiawan Muslim, Bandung: Mizan, 1996.

Made Wahyu Suthedja, Bagaimana Membangun Semangat Staf Pengajar, Semarang: Satya Wacana, 1988.

Mochtar Bukhori, Pendidikan Dalam Pembangunan, Yogyakarta: Tiara Wacana, 1994.

Muhaimin, et. all., Paradigma Pendidikan Islam: Upaya Mengefektifkan Pendidikan Agama Islam di Sekolah, Bandung: PT. Remaja Rosdakarya, 2001 
Nursyamsiyah Yusuf, "Motivasi Menjadi Guru dalam Kaitannya dengan Profil Kinerjanya”, Jurnal Ilmiah Kajian Pendidikan dan Kebudayaan No. 008/II/Maret, Badan Penelitian dan Pengembangan Pendidikan dan Kebudayaan, 1997.

Panji Anoraga, Psikologi Kerja, Jakarta: Rineka Cipta, 1992.

Piet. A. Sahertian, Profil Pendidik Profesional, Yogyakarta: Andi Offset, 1994.

Rusydi AM., "Etos Kerja dan Etika Usaha: Perspektif AlQur`an" dalam Firdaus Effendi, dkk (ed), "Nilai dan Makna Kerja dalam Islam", Jakarta: Nuansa Madani, 1990.

The Liang Gie, Cara Bekerja Efisien, Yogyakarta: Karya Kencana, 1978.

Toto Tasmara, Etos Kerja Pribadi Muslim, Jakarta: PT. Dana Bhakti Wakaf, 1995.

Toto Tasmara, Membudayakan Etos Kerja Islami, Jakarta: Gema Insani Pers, 2002.

WS. Winkel, Psikologi Pengajaran, Jakarta: Grasindo, 1996, cet. ke-4.

Yayasan Penyelenggara Penerjemah al-Qur`an, Al-Qur`an dan Terjemahnya, Surabaya: Mahkota, 1971.

Yusuf bin Ismail al-Nabhani, Mukhtasar Riyād al-Sālihīn, Beirut-Lebanon: Dar Ibnu Hazm, 1996. 
Syarifuddin

Al Amin: Jurnal Kajian Ilmu dan Budaya Islam, Volume 1, No 2, 2018| 239 